\title{
Will There Be a Place for my Life?: Cities, Subjectivities and Geographies of Resistance
}

\section{¿Habrá un Lugar para mi Vida?: Ciudades, Subjetividades y Geografías de Resistencia}

\author{
Martin Savransky \\ Goldsmiths, University of London \\ m.savransky@gmail.com
}

\begin{abstract}
The present paper pursues an encounter between pressing questions in both human geography and psycho-social and cultural theory, namely, between processes of subject-formation and the production of subjectivity and the way these are always already emplaced, enfolded within a culturally signified geography that in turn they come to sustain or contest through different means. The argument, or rather, the invitation, is that insofar as subjectivities take place, it might be promising to regard cities and urban spaces as spaces of subjectivation. Thus, firstly, the question of how it is we come to engender a subjectivity is posed and addressed following performativity theory. Secondly, some of the implications of the proposed notion of 'spaces of subjectivation' are stressed and a theoretical case of abject urban spaces is analysed. Finally, the question of resistance and the possibility of contesting those geographies of subjectivation through geographies of resistance is posed and a possible approach is offered.
\end{abstract}

Keywords: Geography; Subjectivity; Performativity; Escape; Tactics

\section{Resumen}

El presente texto persigue un encuentro de cuestiones de relevancia en los campos de la geografía humana y la teoría psico-social y cultural, es decir, un encuentro entre procesos de formación de la subjetividad y las formas en que estos se encuentran emplazados, envueltos en una geografía cargada de significaciones culturales, que estos mismos procesos contribuyen a sostener o a contestar. El argumento, o mejor, la invitación del presente texto consiste en la propuesta de reflexionar sobre el emplazamiento de la formación de la subjetividad a través de concebir las ciudades y los espacios urbanos como espacios constitutivos de esa formación, es decir como espacios de subjetivación. En primer lugar, entonces, la cuestión de cómo llegamos a habitar una subjetividad es planteada y abordada desde la perspectiva de la teoría de la performatividad. En segunda instancia, algunas de las implicaciones de la noción de "espacios de subjetivación" propuesta son señalados, y un caso teórico de espacios urbanos abyectos es analizado. Finalmente, se plantea la problemática de la resistencia y la posibilidad de contestar geografías de subjetivación a través de geografías de resistencia es valorada e ilustrada.

Palabras clave: Geografía; Subjetividad; Performatividad; Escape; Tácticas 


\section{Introduction: Psycho-Social Theory, Performativity and the Question of the Subject}

Among the myriad of pressing questions that have haunted (psycho-)social and cultural theory for the last decades, what we could call 'the question of the subject' is certainly deserving of a special emphasis. Indeed, an innumerable amount of challenges have been put forth to the Cartesian subject, insofar as it is no longer tenable that subjects be autonomous and self-sufficient, clearly split in mental and bodily dimensions, possessing both an interiority and a relation to an outside; a rational being that can finally address with certainty that "I" am'.

Thus, since Friedrich Nietzsche's (1996, p. 29) "there is no doer behind the deed" via Michel Foucault's Panopticon (1975/1991), a whole genealogy of thought throughout the twentieth century has been concerned with challenging the multiplicity of assumptions that the Cartesian notion of subjectivity entails. As Vikki Bell (2007, p. 11) argues:

[t]here is no resolution of doubt, no passage into certainty, because the subject is itself a locus of effects of his or her surroundings. That is, the subject is produced by historically varying conditions that are in turn sustained by their produced elements.

Thus, instead of a rational, self-contained, autonomous subject we encounter a subject as an effect of the entanglements or foldings of history and power (see for instance Deleuze, 1986/2006). Indeed, we encounter a subject for which 'thinking' as such no longer allows for the certainty of being, for it only provides the possibility of relating to oneself within the limits of certain discursive and symbolic conditions, certain 'régimes of truth', in Foucault's terms, that constrain the ways in which we may relate to and think about ourselves but also stand as the very condition of possibility for the enunciation of an "I" (Butler, 1997a). Indeed, as Judith Butler (2004a, p. 28) argues, thinking about how a subject is formed is thinking about "the ways in which we are, from the start and by virtue of being a bodily being, already given over, beyond ourselves, implicated in lives that are not our own." As Julian Henriques, Wendy Hollway, Cathy Urwin, Couze Venn \& Valerie Walkerdine (1984) argued in a seminal paper on subjectivity and psychosocial studies, the notion of subjectivity involves both an intimate relation to oneself and a form of submission to an order that makes that very first relation of intimacy possible. Subjects, thus, are formed through the ways in which power acts upon bodies: "[p]ower not only acts on a subject but, in a transitive sense, enacts the subject into being. As a condition, power precedes the subject." (Butler, 1997a, p. 13). Being a subject is thus not so much a form of being, but a permanent form of becoming, a process that at the same time requires and conceals its own temporality and its own beginnings (Butler, 1990/1999).

The understanding of this temporality, or what recently has been called, 'subjective time' (Papoulias \& Callard, 2010) is, I would argue, of extreme importance when addressing the question of the subject, for although we might agree that subjects are always already entangled within a historical configuration of power relations that make them possible and also constrain them in different ways, and insofar as inhabiting a subjectivity is not an ontological statement, that is, it is not a form of being, but rather, a process of becoming, how exactly does this process of subject-formation happen? How does one become a subject?

Insofar as any explanation of this process not only attempts to respond to the question posed immediately above but also, and in so doing, always invokes a genealogy of intellectual debates and theoretical positions around this question, this paper does not attempt to give a comprehensive response to this 
question but one among many others (for a more comprehensive map of different positions around the notion of the subject, and moreover, a map that was constructed with geographical notions in mind, see Pile \& Thrift, 1995; see also Lash, 1984). Namely, the assumption that makes this paper possible is one by which the subject comes into being through a reiterative process of citation and enactment of the cultural and social (and spatial, as I will try to show) norms that make her life possible in both corporeal and cultural terms (Butler, 1993). Subjects come into being through the reiterative performance of norms. As Judith Butler (1993, p. 15, emphasis on original) argues:

[t]he process of sedimentation or what we might call materialization will be a kind of citationality, the acquisition of being through the citing of power, a citing that establishes an originary complicity in the formation of the "l" .

Thus, contrary to sociological and social psychological theories of socialization, we do not encounter a subject that internalises a set of norms that lie outside her, as if she was already there from the start, indeed, as if the epistemic trope of her formation were that of an 'encounter' between subjectivity and culture. Instead, the "I" that articulates the grammatical inflection of a relation to oneself, that is, of subjectivity itself, is a bodily "l" that becomes continuously materialised through a temporal process of mimesis of constitutive and regulatory norms of being that make that subjectivity intelligible within a historical period and within a set of cultural conventions. In other words, subject-formation is a process of practice and repetition, of repetitive practices that form the one claiming authority over those practices. The importance of temporality becomes salient once we recognize that, albeit produced as effects of power, subjects are never 'perfect examples of the law', that is, they are not completely determined by the power formations that made them possible in the first place, but are able to resist, re-appropriate, and fail to reproduce the norms that constitute them as such -although not without undergoing the risks of becoming unintelligible- (Butler, 1993). It is in the re-production of normative conventions outside their conventional frameworks, indeed, outside there conventional bodily materialisations, that the relationship between subjects and norms becomes not only reproductive, but also creative, productive, subversive and political.

The subject of contemporary (psycho-)social theory is thus a subject that becomes gendered, racialised, classed, etc., by a repetitive acting that takes the form of a citation of the very norms that at a given time regulate gender, 'race', and class distinctions. Indeed, a world of literature on specific becomings and subject-formations has found place in the last decades, across disciplines. We have been acquainted with the ways in which bodily subjects materialise through the citation of gender norms (Butler, 1990/1999; 1993; 2004b), through the regulatory formations of 'race' (see for instance Bhabha, 1994; Fanon, 1952/2008; Gilroy, 1993; Hall, 1990), the production of class (see Adkins \& Skeggs, 2004; Skeggs, 2003), and also through slightly more specific formations such as the education system (see for example Davies et al., 2001; Walkerdine, 1990), institutionalised psychology and psychotherapy (Foucault, 1976/1998; Rose, 1996), and, most famously, the system of imprisonment and confinement of 'deviancy' (Foucault, 1975/1991), among others.

The present paper -although clearly and crucially inscribed within this tradition of thought- is an attempt to point out the fact that, despite Foucault's (1975/1991) genealogy of imprisonment and punishment is, as Edward Soja (1989) has cleverly remarked, a 'spatial historiography', in that the architectural configuration of the prison, the distribution of in/visibility that it allows, and the cultural significations that are attached to it, render space a central element in the question of subjectivation, we could argue that, 
comparatively, less theoretical attention within this intellectual geneaology has been paid to the ways in which subjects are spatially subjectified (certain texts within post-colonial theory and diaspora studies are of course important exceptions, see for instance Bhabha, 1994; Gilroy, 1993; Yiftachel, 2010; there is also a number of urban and cultural anthropologists that do deal with this question albeit somewhat differently: see Delgado, 2007; also see Kanna, 2010). By this I mean the ways in which subjectivation takes place within certain spatial formations, and moreover, the ways in which this formations of space are always already embedded with cultural significations and norms and thus contribute to the formation of emplaced subjectivities.

Thus, in the following section I will attempt to argue for a way of thinking the link between subjectivity and urban spaces, more specifically, cities ${ }^{1}$-in their entirety or in parts- as spaces of subjectivation. Thinking with and against the work of scholars who have aimed at dealing with both the spatiality of the psyche and the psychic life of space, I will argue that the formation of subjectivities is always already produced in space and also producing space through the very enactment and materialisation of bodies and subjects within culturally signified urban spaces, and that, as such, more attention needs to be paid to the way in which cultural norms operate through space by embedding urban texture with cultural significations and normative imperatives. After this main argument of the paper is presented, I will focus on the ways in which subjects might resist or critically and creatively engage with those very normative formations of space that make emplaced subjectivities possible. More concretely, following the work of Sandro Mezzadra (2005), I will draw on one possible 'tactic' (see De Certau, 1984) by which resistance to normative subjection in cities might be accomplished, namely, by an act of escape.

\section{Will there be a place for my life?: Cities, Abjection and Situating Subjectivation}

As I have argued above, the question of subjectivity in contemporary (psycho-)social and cultural theory is a question not of what subjects are but of how one becomes a subject. Subjectivity is a process of becoming. Moreover, following the tradition of thought on subjectivation that is now known as performativity theory (for a fascinating overview see Bell, 2007), I have argued that to think about subjectivity as a process of becoming, or in other words, to think about subjectivation, is to interrogate the ways in which cultural norms are inscribed into bodies through a process of repetitive citation of those norms, a process that insofar as it engenders intelligible subjectivities, it institutes certain forms of life and precludes others. Indeed, the question of an intelligible life is at the centre of this whole problematic: which lives can be lived and which lives remain utterly unlivable within a certain cultural and historical present?

In a recent reflection on this issue, Judith Butler (2004b, p. 2-3, emphasis added) frames the question of becoming a (gendered) subject in the following way:

If I am a certain gender, will I still be regarded as part of the human? Will the "human" expand to include me in its reach? If I desire in certain ways, will I be able to live? Will

\footnotetext{
${ }^{1}$ In the present text, an analytical distinction between "urban spaces" and "cities" is made, one that, moreover, will let us think the latter through the former, namely, by understanding the former as the lived space were urban bodily experience takes place, and the latter by an abstraction of those spaces through geographical organization. Although the following exceeds the scope of this paper, this distinction allows as well for an interesting comparative question between the internal cultural-spatial heterogeneity of a city and its outer 'image', the one it projects to the outside, and the sort of subjections to that cultural connotation of the city as a whole that might be created when a subject is discursively situated as a inhabitant of that city in a diasporic encounter.
} 
there be a place for my life, and will it be recognizable to others upon whom I depend for social existence?

Indeed, this is a rich and complex set of questions for it establishes and intimate relation between forms of subjectivity and a normative notion of who counts as human, and ultimately, who, as human, is allowed to live and who is excluded from the living. It also suggests the important extent to which subjectivation is not a question of fashionable self-making, as some postmodern thinking would have it, but a matter of survival (see Bell, 1999; 2008) and thus, how thinking about subjectivation is to be regarded as a form of ethical and political thought about the ways in which certain lives are made possible while others are left without a place. But what, for the present paper, seems to me to be of great help in this quotation is the way in which the question of subjectivation is itself posed as a question of there being a place for "my" life. Indeed, one could argue, a spatial logic is always already at work in the theoretical reflections upon subjectivity. But I think this is only partially the case. Let me explain, briefly.

The place to which Butler is alluding to here is, most certainly, a metaphoric place constituted through the cultural expansion of the normative constraints upon any notion of the 'human', the expansion of a cultural space whereby desiring subjects can be allocated in their multiplicity, without reducing that multiplicity to forms of heterosexism and without expelling from that 'place' those who desire in ways other than what the hetero-normative régime of subjectivity allows.

And indeed it has been often the case that, on the one hand, theories of subject-formation have paid less attention to the ways in which subjectivities become possible through their specific localizations in certain places, or how space is embedded with cultural significations and norms to such an extent that the bodies that inhabit, walk through, live in, and perform daily activities, therefore (re)producing those spatial formations, end up embodying those significations. With the exception of some important insights in Postcolonial Studies, Diaspora Studies, and Urban Anthropology, where the question of migration and travel, and therefore, some notion of space, becomes relevant when thinking diasporic and post-colonial subjectivities, few theoretical studies of subject-formation or urban theory engage with the way in which urban life-forms are made possible through normative codifications of space (cf. Delgado, 2007; for an extended argument around this issue see Pile, 1996). On the other hand, although one could engage with hundreds of empirical studies of urban life and read them through the lens of subjectivation and performativity, very few of those studies actually adopt such a lens themselves (for some recent and interesting exceptions see Pine, 2010; Platt, 2011).

Thus, my invitation reads: what if one where to spatialise Butler's aforementioned question? Indeed, if 'place' in her question is a metaphor for the relative expansion of cultural intelligibility, how could one think about non-metaphoric places, or more concretely, urban spaces and their relationship to forms of subjectivity? Perhaps the question could read as follows: Will there be a place for my life here/there? Indeed, this addition of an indexical of place to the question of subjectivation immediately points to the need to situate the formation of subjectivity. Thus, my argument is that in the same way that gender, class, ethnic and other differences open up cultural 'places' for the habitation of subjectivities, cities and neighborhoods are also embedded in cultural significations through which constitutive norms circulate and mark the bodies that inhabit them in different ways. As Steve Pile (2005, p.3) argues somewhat differently in the introduction to his Real Cities: 
[s]omething about city life lends itself to being read as if it had a state of mind, a personality, as having a particular mood or sentiment, or as privileging certain attitudes and forms of sociation. It is quite clear that New York is not New Orleans, that London is not Singapore, that Paris is not Berlin. For sure, this has something to do with the buildings: with their built form their super-structures and infrastructures of the city. For sure, it has something to do with the way people live their lives in cities, with their cultures and customs, with how they treat strangers, with their differences and indifferences.

Thus, insofar as the formation of subjectivities takes place, it follows that there must be a where in which this taking place occurs, and that, in an important sense, this where might be related to forms of urbanity. As Ash Amin \& Stephen Graham (1997, p. 420) note, contemporary cities are "complex performative arenas where relational webs weave layers of order between heterogeneous social groups, filières of firms, governance agencies, etc." Thus, following Pile, I suggest we can think the ways in which cities become spaces of subjectivation -and indeed, they become subjects themselves (see Pile, 2005)- both through a spatial or architectural logic, or through its 'buildings', and through the way in which certain forms of life -and all the practices involved in "living" in (parts of) a city, such as moving, using public or private transportation, frequenting certain public and private places as a result of one's own residential or work location, engaging in forms of spatial discursive interactions, etc.-, certain modalities of subjectivity, or what he calls 'attitudes and forms of sociation' are privileged while others are projected to an outside.

What we are arguing for here is of course not an innovation but an additive invitation to connect performative theories of subjectivity to an already significant line of interrogating space. In this sense, marxist thinkers such as Frederic Jameson (1992), Edward Soja (1989; 2000) and David Harvey (1990) have most famously analysed the ways in which post-fordist forms of production have induced new architectural forms, new urbanization and urban design strategies. In turn, this are said to contribute to the production of fragmented spaces and thus to the enfolding of these spaces into forms of postmodern subjectivity.

On the other hand, studies in urban sociology and in discursive social and environmental psychology (Aiello \& Bonaiuto, 2003; Di Masso, 2007; Dixon, 2001; Dixon \& Durrheim, 2000; 2004; Stokoe \& Wallwork, 2003; Wacquant, 2007) have provided interesting accounts of how people use spatial significations and metaphors discursively to regulate social relations and notions of place-identity.

Even though these are all highly valuable accounts of how subjects are inscribed through spatial formations and how they manage spatial logics and discourses in the production of self/other distinctions and also, in the productions of insides and outsides, I believe an account focused on the processes of subject-formation might help as a supplement, if not a partial overcoming, of some of the limitations presented by other approaches. Let me sketch these limitations briefly.

On the one hand, when we regard the literature concerning the relationship between economic relations of production, architectural forms and types of subjectivity, I would argue that what is basically lacking in this conception is, namely, a theory of subject-formation through the incorporation of norms. In these texts, it is often the case that the link between these elements is read only in cultural and political terms, and although the correlation between forms of urbanisation and forms of life is succinctly stressed, the 
psychic and bodily processes through which urban forms come to shape subjective realities remain rather unspecified.

On the other hand, regarding the second body of literature just presented, the focus on the pragmatics of discourse and the public displays of spatial metaphors, although extremely valuable for an analysis of 'the politics of place' and the ways in which subjects negotiate spatial identities, it often ends up presenting the formations of subjectivity as a form of 'management' of discourse about self and others. Thus, it often neglects the way in which norms not only may be negotiated by means other than those of discursive interaction but also, and of equal importance, how they are constitutive of subjects themselves, that is, the way in which the spatial inscription of norms is constitutive of what kinds of subjects are possible in a given spatial formation, and thus, the extent to which those inscriptions are not always readily open to being spoken about, 'managed' and pragmatically negotiated without the risk of becoming unintelligible, of making one's life utterly unliveable (see Adams, 2010).

In this regard, I believe one interesting example to start thinking about the ways in which the cultural significations of urban spaces inscribe bodily subjects through a process of performativity, and albeit it shares some of the difficulties mentioned aboveARTíCULOS, is Loïc Wacquant's (2007) notion, following the work of Erving Goffman (1963), of "territorial stigmatisation". In his account, what Wacquant names "advanced marginality", which, among other aspects, entails a "functional disconnection of dispossessed neighbourhoods from the national and global economies, and the reconfiguration of the welfare state into an instrument for enforcing the obligation of paid work in the polarizing city" (2007, p. 67), adopts a spatial logic through the inscription of 'penalised spaces' which induce a form of 'territorial infamy' by which certain marginal urban spaces ${ }^{2}$ at the heart of the contemporary metropolis become the site of inscription of cultural significations of abjection, guilt and shame. Although Wacquant (2007, p. 67) aligns "territorial stigmatisation" with Goffman's stigma category of "race, nation and religion" instead of that of "abominations of the body" or "blemishes of individual character", his following description of the strategies of disidentification and disavowal used by inhabitants of such spaces shows how territorial stigmatisation attaches itself to embodied subjectivities in significant ways:

People there [i.e. inhabitants of stigmatised territories] commonly hide their addresses, avoid having family and friends visit them at home, and feel compelled to make excuses for residing in an infamous locale that stains the image they have of themselves. (2007, p. 68)

Although Wacquant moves rapidly into a consideration of how subjects 'manage' this spatial stigma, and thus argues that, as such, and unlike the other stigmas of "nation, race and religion", this one can be "quite easily dissimulated and attenuated -even annulled - through geographic mobility" $(2007, \text { p. } 67)^{3}$, I believe this celebration of 'management' needs to be deferred and that a more thorough exploration of

\footnotetext{
${ }^{2}$ Some of the examples given are La Courneuve in Toulouse, South Central Los Angeles, The Bronx in New York, Neuköln in Berlin, and one could easily think of others such as El Raval or Santa Coloma in Barcelona, Seven Sisters, Brixton and the far South in London, or the Shanty-town "Villa 31" in Buenos Aires, etc.

${ }^{3}$ Although in the next section I will argue with Mezzadra (2005) that geographic mobility, or what he calls "exercising the right to escape", might be regarded as a way of resisting the subjectifying effects of urban space, such possibility remains far from being "quite easily" dissimulated, attenuated, or annulled. It rather implies the taking up of a critical and spatial distance with regards to a certain space of subjectivation and, at the same time, the taking of a risk towards inhabiting new spaces that might have less damaging subjectifying effects, a risk that always entails the possibility of becoming unintelligible.
} 
the constitutive nature of such an abject signification of place in the production of subjectivity is called for. Indeed, the inhabiting of a stigmatised territory follows and haunts the subject while within and outside her neighbourhood, forms part of an abject site of her subjectivity, a part of herself that needs to be covered, concealed, even expelled, hidden from the view of others (see Kristeva, 1984). Indeed, inhabitants of stigmatised neighbourhoods become subjects of that space and, as such, are subjected to the spatial norms that form and distribute a whole geography of subjectivity among the different sites of an urban territory. They do not only perform daily bodily and discursive practices that directly relate to the space they inhabit -locating their 'home' within it, doing daily shopping, frequenting certain bars and other leisure places, interacting with neighbours, learning how to move around the area, and so on- thereby enacting and incorporating the spatial norms at stake, shaping their spatial behaviour and subjectivity, they also, as it were, bring those significations with them in their mundane intra-city mobilities that are prompted by contemporary forms of economic geography - Wacquant's example of hiding or showing their address in a job interview is for this respect a quite telling one.

Moreover, if we take into account that the abjection of such spaces is "superimposed on the already existing stigmata traditionally associated with poverty and ethnic origin or postcolonial immigrant status, to which it is closely linked but nor reducible" (Wacquant, 2007, p. 67), we can begin to realise that the production of subjects through the spatial inscription of norms is not just a question of discursively managing our public identity and concealing where we come from, but a bodily inscription that reinforces a somatic norm related to the racial regulations of the occupation of urban spaces (Puwar, 2004). The cultural significations of an abject urban space become attached to bodies that carry those significations and that, in turn, become sites of abjection themselves (for a vividly first-person account see Fanon, 1952/2008).

Furthermore, I believe that Wacquant's rapidity in pointing towards resisting these place-identifications misses yet another point. In his account of the strategies of disavowal quoted above, the sort of subject that is implicitly invoked is a form of autonomous subject, even an adult subject, insofar as she inhabits that territory 'alone' -without friends or family-. But as we know, this if often not the case. Entire families may reside in these areas -as do in others-, and other forms of primary complicities and interdependencies might be produced in such a way that this abject urban spaces stand in a much more ambivalent relation to those subjects than that suggested by Wacquant, namely, as a simple burden to the subject's "image" of herself. What is missing here is, significantly, the extent to which, from the outset, this kind of territories, as spaces of subjectivation, are also the conditions of possibility for forms of subjectivity that are not possible elsewhere and that, in bringing subjects to life, they become the very origin, indeed, a spatial point of departure for the subject who then might or might not be able to pragmatically rearticulate its own formation into other, perhaps socially preferred, narrative terms, for "[t]he one story that the "l" cannot tell is the story of its own emergence as an "l" who not only speaks but comes to give an account of itself" (Butler, 2005, p.66).

Thus, to regard cities, and certain urban spaces within them as spaces of subjectivation is to think about the ways in which subjectivities are produced through regulatory schemes of space and place, both in its material and architectural formations and also in the cultural significations in which spaces are embedded. The focus on subject-formation in relation to urban spaces, thus, also allows us to think of the way in which both abject spaces and those regarded as "normal", that is, those instituting the spatial norm, remain in a relation of ambivalence toward the subjectivities they engender, constraining and marking the bodies that inhabit them in limiting and sometimes damaging ways, but also enabling forms 
of life that have been precluded from other sites. The attention to the constitutive, bodily and lived nature of such processes, doubtless, renders the possibility of "managing" one's own subjectivity and public identity much more problematic and, indeed, difficult than other approaches have implicitly suggested.

However, this does not mean that resistance is out of the picture. In the following section, I will focus on the forms in which a certain resistance to citing the norms of power might be exerted, how a critical subjectivity might be brought into being out of such resisting practices, and what it might entail for thinking what Steve Pile \& Michael Keith (1997) have called "geographies of resistance".

\section{Geographies of Resistance: Subjectivity, Tactics of Counter- Mapping, and the Right to Escape}

The question of whether effective resistance against the inciting forces of subjectivation can be exerted is, needless to say, an open question. Depending on the intellectual genealogy one is informed by, the possibility of an emerging agency may appear unimaginable, for, if power is what forms the subject, and that subject constitutes itself through an acting that is power (Butler, 1993), then the re-articulation of resisting practices against those forces that constitute the subject might seem impossible, or at least, the cost of it would seem to be the very possibility of subjectivity itself.

In this sense, for instance, the kind of governmentality critique developed by Nikolas Rose (see for instance, 1996) and others, one which Critical Psychology has certainly embraced as its own, rests upon the assumption that the only way to theorise social change without falling back into dualisms of all kinds and without reintroducing that safe interiority inside the head of individuals, is to explain social change by means of simultaneous technologies of subjectivation that may produce competing forms of subjectivity. Thus, whenever we think we are seeing an act of resistance, what we really see is another force, another power formation (for a critical account of the attitude with which this sort of thinking exercises critique see Stengers, 2008). However, as Steve Brown \& Paul Stenner (2009) have convincingly argued, this kind of work draws upon a very selective reading of Foucault, one which does not account for ways in which subjects may deal with normativity in more creative ways.

The tradition of thought on subject-formation that I have tried to put forth here, namely, that of performativity theory, allows more space for thinking the possibility of resistance. Indeed, resistance is always what haunts, with every repetition, with every act, the very process of subject-formation. Insofar as the formation of subjectivity is co-extensive with history but unfolds itself -or perhaps, enfolds itself- in what, following Constantina Papoulias \& Felicity Callard (2010), we have called "subjective time", that is, the time of lived experience, subjectivation is a temporal process of reiteration or iteration (Derrida, 1988) of norms that come to produce an intelligible "l". The possibility of resistance within performativity theory lies within the logic of that reiteration, namely, in the fact that, albeit brought about as a mimesis, every act of repetition has to be made anew, and in each act there is the possibility of failing to comply to the rule one was supposed to mime, but also of engaging with norms in critical ways, namely, by the subversion of the constraints of citation itself, by miming the conventional formulae in non-conventional ways and thus re-appropriating the very performance that, therefore, no longer stages a scene of reproduction: "[t]he possibility of a resignification of that ritual is based on the prior possibility that a formula can break with its originary context, assuming meanings and functions for which it was never intended." (Butler, 1997b, p. 147). In this sense, if at the beginning of this essay we stated that subject- 
formation was an ongoing process of practice and repetition, what this section invites us to consider is, thus, the extent to which subject-formation is always already a process of differentiation.

The conception of resistance just outlined here bares some interesting similarities with Michel de Certau's (1984) spatial characterisation of power and resistance in terms of strategies and tactics. In his account, strategies are rationalisations of power that "seek first of all to distinguish [their] 'own' place, that is, the place of its own power and will, from an environment." (1984, p. 36). This of course gives power the "mastery of places through sight" allowing for a field of visibility that "can transform foreign forces into objects that can be observed and measured, and thus control and 'include' them with its scope of vision" (1984, p. 36).

By contrast, a tactic is "a calculated action determined by the absence of a proper locus. [...] The space of a tactic is the space of the other" $(1984$, p. 37$)$. This non-place of tactics does not necessarily pose a problem to resistance for, "[t]his nowhere gives a tactic mobility, to be sure, but a mobility that must accept the chance offerings of the moment, and seize on the wing possibilities that offer themselves at any given moment" (p.37). Thus, a tactic is an art of twisting the game of power in the very space of power, it is about:

vigilantly mak[ing] use of the crack that particular conjunctions open in the surveillance of proprietary powers. It poaches in them. It creates surprises in them. It can be where it is least expected. It is a guileful ruse. (p. 37).

Moreover, Pile (1997, p 16) suggests that, at first glance, de Certau's distinction is

suggesting that the powerful control space and that resistance can do no more than act out of place, but it can also be argued that tactics or resistance have at least two 'surfaces': one facing towards the map of power, the other facing in another direction, towards tangible, invisible, unconscious desires, pleasures, enjoyments, fears, angers and hopes - the very stuff of politics.

Thus, the resistance of subjectivation through spatial means is about slipping through the cracks of the spatial grid of power not only to subvert that very grid and prevent it from occupying its own shadows but also by projecting our desire elsewhere, or indeed, by gradually transforming the apparent symbolic fixity of the map through the surreptitious insinuation of counter-mapping. Among these tactics of countermapping is of course the tactic of geographical mobility. How is geographical mobility, most often also migration, a spatial tactic of resistance to a space of subjectivation?

Indeed, if the question seems rather counter-intuitive at first, this is probably due to the way in which mainstream research on migration studies has tried to account for why people move. Thus, what Mezzadra (2005) calls the 'new orthodoxy' on migrations, that is, the new economics of migration (see for instance Portes 1997), stresses that human mobilities are primarily determined by objective economic factors and by influence of family and communitarian 'networks'. We are used to understanding "the problem of" migration as a kind of forced or induced movement due to catastrophic economic conditions, and therefore strip the migrant subject of any political valence by converting her into the ideal -but also often impossible- subject of the welfare state.

As Mezzadra (2005) points out, there are at least three issues that are neglected or misguiding in this approach. First of all, the new economics perspective is marked by a "reference to migrations as a 
confirmation of the increasing social mobility that would characterise the capitalist system and the american citizenship" (Mezzadra, 2005, p. 146. Own translation). Thus, processes of stigmatisation and discrimination that are emphatically stressed within this discourse, tend to be regarded as collateral effects of capitalism, which are never really put into question (see also Savransky, 2011).

Secondly, this approach tends to strip away all political and social confrontations from the process migration and these are rendered as simple dependent variables of a fundamentally 'commercial' model of citizenship (Honig, 2001).

Finally, they leave out the subjective determination and relative autonomy of migration as the exercise and performance of a 'right to escape', as a refusal to be subjected to a given space and to a certain labour culture through the act of fugue. On the contrary, and in Mezzadra's own terms (2005, p. 144, emphasis in original. Own translation.), 'the [perspective of the] autonomy of migrations refers to the surplus of subjective practices and demands that find expression in migratory movements in relation to the objective practices that determine them'.

Against the privileging of 'objective causes' for the explanation of migration, Mezzadra (2004, p. 270. emphasis in original. Own translation) invites us to:

underline the fact that for migrations to exist, there must be an individual motion (made concretely by a concrete woman or man, embedded in family and social 'networks', but nonetheless capable of agency) of desertion from the field where those 'objective causes' operate, a reclaiming precisely of a 'right to escape', which even if most of the time unconsciously, constitutes a material critique of the international division of labour and marks profoundly the subjectivity of the migrant also in the country where she/he chooses to settle down.

This notion of autonomy and escape, however, remains in sharp contrast to any heroic notion of the migrant subject or any postmodern celebration of nomadism for as Mezzadra (2005, p. 16. Own translation) stresses, "[i]n this research [...] the possibility of talking of a subject in 'heroic' terms is criticised from the very beginning and attention is given to the sum of processes of subjectivation that form the texture of social relations". Thus, Mezzadra presents us with an account of migrant subjectivities that escape a certain space of subjectivation as a means of resisting pervasive subjectifying conditions, while, as it is clearly stated in the quote above, this does not imply any form of heroism nor a pure selfdetermination but a subject that is herself possible by means of those same social conditions that wishes to overcome. Thus, in every tactic of resistance, in every act of counter-mapping and escape, there is a risk of loosing oneself, of remaining unintelligible, or, to continue with the metaphors of visibility, a risk of being unable to come back to light.

In the process of escaping, indeed a tactic of counter-mapping through geographical mobility, the subject is not build anew, for that would entail, precisely, a moment of complete darkness, a leap into unintelligibility and psychosis. On the contrary, "the very social [and urban, we could add] texture of the place of origin is modified by new relations that are produced at the place of arrival." (Mezzadra, 2005, p.18. Own translation). Thus, the citing of conventional formulae in clearly unconventional places not only allows for the exercise of resistance to the formulae and to the convention of place itself, but in its very enactment, it disrupts the convention by subverting its appropriate place of action, and thus produces space as a sort of counter-mapping of action and subjectivity, a geography, indeed, of resistant practices. 
In this way, migration stops being merely a "flow", determined by economic conditions of a global market that pulls and pushes world-population around the globe in accordance with its demands. Migration becomes an assertion of subjectivity in regards to its emplacement, it becomes about the re-making of geography through tactics of counter-mapping, or, as Soja (2000, p. 281) would argue, it becomes about the very "social production of human spatiality":

This involvement in producing and in already produced spaces and places is what all those who are oppressed, subordinated, and exploited share, and it is the shared consciousness and practice of an explicitly spatial politics that can provide and additional bonding force for combining those separate channels of resistance and struggle that for so long have fragmented modernist equality politics. (Soja, 2000, p. 281).

Thus, regarding migration, with Mezzadra (2005), as the production of a geography of resistance, allows us to fathom ways in which subjectivity, as a permanent becoming, is always an emplaced process, formed in, through, and by space as well as forming space through either the re-production of the spatial strategies and the mimesis of the spatial norm, or through exercise of resistant tactics of countermapping, dislocation and escape.

\section{Concluding Remarks: On Subjectivity and Other Spaces}

In the present paper I have attempted a twofold task. On the one hand, I have intended to approach the issue of human geography and the social production of spatiality through the question subject-formation or subjectivation. On the other hand, I have tried to emplace the very process of subject-formation in the signification of urban spaces and places, by thinking them as spaces of subjectivation, in order to understand the way in which normative significations of place become attached to subjectivities and bodies, constraining them in relevant ways, and also, simultaneously and paradoxically, enabling them, becoming constitutive of subjects themselves, allowing for a place, however abject, for a subject's life.

In the process, I hoped to have shown that this way of thinking the relationship between subjectivity and spatiality is at the same time informed by and may, in turn, also critically supplement other approaches that emphasise different dimensions of that disciplinary intersection between the geographical and the psycho-social, space and subjectivity.

Lastly, I have attempted to approach the question of resistance as regards the subjectifying effects of space through a consideration of de Certau's (1984) distinction between strategies and tactics, and have provided an exemplary case to think about geographical mobility as a form of resistance to potentially damaging or undesired forms of spatial subjectivation by understanding, with Mezzadra $(2004 ; 2005)$, the subjective determination of migratory movements as acts of escaping certain socio-spatial conditions of subject-formation and thus engendering a spatialised critical subjectivity. In doing this, I hope to have shown that, as Pile (1997, p. 16, my emphasis) suggests:

[i]f de Certau is right, resistance cannot be understood as a face-to-face opposition between the powerful and the weak, nor as a fight that takes place only on grounds constituted by structural relations - because other spaces are always involved: spaces 
which are dimly lit, opaque, deliberately hidden, saturated with memories, that echo with lost words and the cracked sounds of pleasure and enjoyment.

Thus, the production of these other spaces through a tactic of counter-mapping is also the attempt at remaking geography, at producing different places for my life, at expanding the spatial boundary whereby certain lives are rendered livable while others become utterly unlivable. I repeat, thus, my invitation to other researchers and thinkers to continue enquiring in this promising and complex field of interrelation and mutuality between the spatial formations of subjectivity and the social production of space.

\section{Acknowledgements}

I would like to thank the Fundación Caja Madrid for providing me with the necessary funding to undertake the research that made possible the writing of this paper. I would also like to thank the guest editors of this volume, Andrés Di Masso and Angela Castrechini for all their work and welcoming patience. I am also thankful for the comments and suggestions made by two anonymous reviewers and by the corrector. Finally, my thanks also go to Sean Legassick and Melissa Salm for discussing these ideas with me while this paper was under construction, and to Jose Hernandez and Tomeu Vidal for their comments on a previous draft of this paper. Despite all of them being great inspirational sources, any mistakes this paper might have are my responsibility alone.

\section{References}

Adams, Matthew (2010). Losing One's Voice: Dialogical Psychology and the Unspeakable. Theory \& Psychology, 20, 342-361.

Adkins, Lisa \& Skeggs, Bev (2004). Feminism after Bourdieu. London: Blackwell.

Aiello, Antonio \& Bonaiuto, Marino (2003). Rhetorical Approach and Discursive Psychology: The Study of Environmental Discourse. In Mirilia Bonnes, Terence Lee, \& Marino Bonaiuto (Eds.), Psychological theories for environmental issues (pp. 235-270). Hants: Ashgate Publishing.

Amin, Ash \& Graham, Stephen (1997). The ordinary city. Transactions of the Institute of British Geographers, 22, 411-429.

Bell, Vikki. (1999). Feminist Imagination. London: Sage.

Bell, Vikki (2007). Culture \& Performance. London: Berg.

Bell, Vikki. (2008). From Performativity to Ecology: On Judith Butler and Matters of Survival. Subjectivity, $25,395-412$.

Bhabha, Homi. (1994). The Location of Culture. London: Routledge.

Brown, Steven \& Stenner, Paul (2009). Psychology Without Foundations: History, Philosophy, PsychoSocial Theory. London: Sage.

Butler, Judith (1990/1999). Gender Trouble: Feminism and the Subversion of Identity. New York: Routledge. 
Butler, Judith (1993). Bodies That Matter: On the Discursive Limits of Sex. New York: Routledge.

Butler, Judith (1997a). The Psychic Life of Power: Theories in Subjection. Stanford: Stanford University Press.

Butler, Judith (1997b). Excitable Speech: A Politics of the Performative. New York: Routledge.

Butler, Judith (2004a). Precarious Life. New York: Verso.

Butler, Judith (2004b). Undoing Gender. New York: Routledge.

Butler, Judith (2005). Giving an Account of Oneself. New York: Fordham University Press.

Davies, Bronwyn; Dormer, Suzy; Gannon, Sue; Laws, Cath; Rocco, Sharn; Taguchi, Hillevi \& McCann, Helen (2001). Becoming Schoolgirls: the ambivalent project of subjectification. Gender \& Education, 13, 167-182.

De Certau, Michel (1984). The Practice of Everyday Life. Berkeley: University of California Press.

Deleuze, Gilles (1986/2006). Foucault. London: Continuum.

Delgado, Manuel (2007). Sociedades Movedizas: Pasos hacia una antropología de las calles. Barcelona: Anagrama.

Derrida, Jacques (1988). Limited Inc. Evanston, IL: Northwestern University Press.

Di Masso, Andrés (2007). Usos retóricos del espacio público: la organización discursiva de un espacio en conflicto. Athenea Digital, 11, 1-22.

Dixon, John (2001). Contact and Boundaries: 'Locating' the Social Psychology of Intergroup Relations. Theory \& Psychology, 11(5), 587-607.

Dixon, John \& Durrheim, Kevin (2000). Displacing Place-Identity: A discursive approach to locating self and other. British Journal of Social Psychology, 39(1), 27-44.

Dixon, John \& Durrheim, Kevin (2004). Dislocating Identity: Desegregation and the transformation of place. Journal of Environmental Psychology, 24(4), 455-473.

Fanon, Franz (1952/2008). Black Skin, White Masks. London: Pluto Press.

Foucault, Michel (1975/1991). Discipline \& Punish: The Birth of the Prison. London: Penguin.

Foucault, Michel (1976/1998). The History of Sexuality: The Will to Knowledge. Vol 1. London: Penguin.

Gilroy, Paul (1993). The Black Atlantic: Modernity and Double Consciousness. London: Verso.

Goffman, Erving (1963). Stigma: Notes on the Management of Spoiled Identity. New York: Simon \& Schuster.

Hall, Stuart (1990). Cultural Identity and Diaspora. In Jonathan Rutherford (Ed.), Identity: Community, Culture, Difference (pp. 222-238). London: Lawrence and Wishart. 
Harvey, David (1990). The Condition of Postmodernity: An Enquiry into the Origins of Cultural Change. Malden MA: Blackwell Publishers.

Henriques, Julian; Hollway, Wendy; Urwin, Cathy; Venn, Couze \& Walkerdine, Valerie (1984). Changing the Subject: Psychology, social regulation and subjectivity. London: Methuen \& Co.

Honig, Bonnie (2001). Democracy and the Foreigner. Princeton. NJ: Princeton University Press.

Jameson, Frederic (1992). Postmodernism: Or, The Cultural Logic of Late Capitalism. New York: Verso.

Kanna, Ahmed (2010). Flexible Citizenship in Dubai: Neoliberal Subjectivity in the Emerging 'CityCorporation'. Cultural Anthropology, 25, 100-129.

Kristeva, Julia (1984). The Powers of Horror: An Essay on Abjection. New York: Columbia University Press.

Lash, Scott (1984). Genealogy and the Body: Foucault/Deleuze/Nietzsche. Theory, Culture \& Society, 2 , $1-17$.

Mezzadra, Sandro (2004). The Right to Escape. Ephemera: Theory \& Politics in Organization. 4, 267275.

Mezzadra, Sandro (2005). Derecho de Fuga: Migraciones, Ciudadanía y Globalización. Madrid: Traficantes de Sueños.

Nietzsche, Friedrich (1996). On the Geneaology of Morals. Oxford: Oxford University Press.

Papoulias, Constantina \& Callard, Felicity (2010). Biology's Gift: Interrogating the Turn to Affect. Body \& Society, 16, 29-56.

Pile, Steve (1996). The Body \& The City: Psychoanalysis, Space and Subjectivity. London: Routledge.

Pile, Steve (1997). Introduction: Opposition, political identities and spaces of resistance. In Steve Pile \& Michael Keith (Eds.), Geographies of Resistance (p.1-32). London: Routledge.

Pile, Steve (2005). Real Cities. London: Sage.

Pile, Steve \& Keith, Michael (1997). Geographies of Resistance. London: Routledge.

Pile, Steve \& Thirft, Nigel (1995). Mapping the Subject: Geographies of Cultural Transformation. London: Routledge.

Pine, Adam (2010). The performativity of urban citizenship. Environment and Planning A, 42, 1103-1120.

Platt, Louise (2011). Liverpool 08 and the performativity of identity. Journal of Policy Research in Tourism, Leisure and Events, 3, 31-43.

Portes, Alejandro (1997). Immigration Theory for a New Century: Some Problems and Opportunities. International Migration Review, 31, 799-825.

Puwar, Nirmal (2004). Space Invaders: Race, Gender and Bodies Out of Place. London: Berg. 
Rose, Nikolas (1996). Inventing Our Selves: Psychology, Power and Personhood. Cambridge: Cambridge University Press.

Savransky, Martin (2011). Ciudadanía, Violencia Epistémica y Subjetividad. Revista CIDOB d'Afers Internacionals, 95, 113-123

Skeggs, Bev (2003). Class, Self, Culture. London: Routledge.

Soja, Edward (1989). Postmodern Geographies: The Reassertion of Space in Critical Social Theory. London: Verso.

Soja, Edward (2000). Postmetropolis: Critical Studies of Cities and Regions. Oxford: Blackwell.

Stengers, Isabelle (2008). Experimenting with Refrains: Subjectivity and the Challenge of Escaping Modern Dualism. Subjectivity, 22, 38-59.

Stokoe, Elizabeth \& Wallwork, Jodi (2003). Space invaders: the moral-spatial order in neighbour dispute discourse. British Journal of Social Psychology, 42(4), 551-569.

Wacquant, Loïc (2007). Territorial Stigmatization In the Age of Advanced Marginality, Thesis Eleven, 91(1), 66-77.

Walkerdine, Valerie (1990). Schoolgirl Fictions. London: Verso.

Yiftachel, Oren (2010). Critical theory and 'gray space': Mobilization of the colonized. City, 13, 246-263.

\section{Historia editorial}

Recibido: 08/07/2011

Aceptado: 02/08/2011

\section{Formato de citación}

Savransky, Martin (2012). Will There Be a Place for my Life?: Cities, Subjectivities and Geographies of Resistance . Athenea Digital, 12(1), 191-206. Disponible en http://psicologiasocial.uab.es/athenea/index.php/atheneaDigital/article/view/Savransky

Usted es libre de copiar, distribuir y comunicar públicamente la obra bajo las siguientes condiciones:

Reconocimiento: Debe reconocer y citar al autor original.

No comercial. No puede utilizar esta obra para fines comerciales.

Sin obras derivadas. No se puede alterar, transformar, o generar una obra derivada a partir de esta obra.

Resumen de licencia - Texto completo de la licencia 